\title{
Challenges of Renewable Energy Sources (RES) in Developing Countries and the Way Forward
}

ISSN: 2576-8840

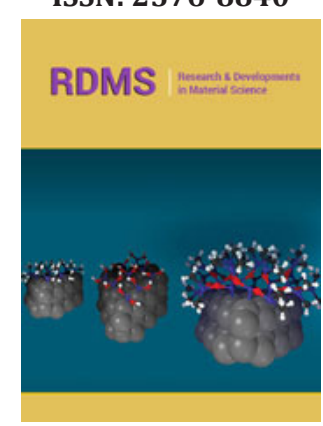

*Corresponding author: Omorogiuwa Eseosa, Department of Electrical/Electronic Engineering, Faculty of Engineering, Nigeria

Submission: 紫 August 26, 2020

Published: 制 September 14, 2020

Volume 14 - Issue 1

How to cite this article: Omorogiuwa Eseosa. Challenges of Renewable Energy Sources (RES) in Developing Countries and the Way Forward. Res Dev Material Sci. 14(1). RDMS.000828. 2020. DOI: 10.31031/RDMS.2020.14.000828

Copyright@ Omorogiuwa Eseosa. This article is distributed under the terms of the Creative Commons Attribution 4.0 International License, which permits unrestricted use and redistribution provided that the original author and source are credited.

\author{
Omorogiuwa Eseosa* \\ Department of Electrical/Electronic Engineering, Nigeria
}

\section{Opinion}

\section{High initial cost of acquisition and installation}

The high initial acquisition cost when compared to utilizing the conventional sources from power utility companies has resulted to a serious setback in the use of Renewable Energy Sources (RES) as an alternative to power generation in developing countries. Cost of acquiring renewable energy system increases as the power system capacities increases whether mini, micro and macro. It should be worthy of note that acquiring and installing RES for power generation is beyond the reach of an average individual in terms of his/her income. One -fourth of the world population resulting to well over 1.6 billion people live without access to electricity. Three hundred and thirty three (333) million Africans live below poverty line of one dollar per day and in every minute that passes by, there is every likelihood that three Africans are likely to fall within this poverty bracket. Moreso, cost of acquiring the least rated capacity of renewable energy is far above the minimum wage as earned in most developing nations.

\section{Government policies and will towards enhancing and promoting the development of renewable energy in developing nations}

The demand for electricity is rising at what could be at least $2.5 \mathrm{~kW}$ per person using Nigeria as an example of the most populous developing nation. If at a conservative figure of 180 million population, then what is required is about $450 \mathrm{GW}$ of electricity to effectively service the energy demand, thus the need for government policies to favor the utilization of RES. Unfortunately, there are no effective policies that favor the utilization of RES and as such have discouraged the investment of individuals, corporate organizations, and companies towards investing in this sector for power generation. There is also little or no serious commitment by the government towards mitigating environmental pollution via utilization of fossil fuels. There should be favorable government policies on power generation for RES that will be different from the conventional fossil fuel generating sources. These policies should favor reduction or total exemption in tax payment, tariff plan, low interest loans, subsidies in RES utilization, custom duty waivers, tax rebate to encourage people to own solar powered plants, government sponsored programs on RES, etc.

\section{Lack of adequate user awareness}

RES penetration is yet to reach the critical stage of mass awareness creation to enable greater number of the populace to buy into the concept and then see it as a must have though it is still at its infant stage. Starting from basic education down to nursery, primary, secondary and tertiary institutions, there is very poor awareness of RES utilization by individuals. 
Serious enlightenment on discouraging the use of fossil fuels due to its negative impact on the overall ecosystem and the immediate environment in terms of pollution and health implication should be the new narrative and transferred to future generations. RES awareness should also cut across individuals, corporate organizations, companies, business owners, decision makers, owners of business and personnel involved in the business of RES technology and its utilization and the public.

\section{Insecurity and fear of unknown affecting foreign investment}

Policy inconsistencies, poor governance, insecurity, kidnap, insurgency, political apathy, human rights violation, hostage taking etc has negatively affected the attraction of foreign investors to developing nations. These have resulted to a very big threat to the overall development of the developing nations socially, politically, economically and infrastructurally. Foreign partners are highly reluctant and discouraged to neither invest a penny nor even give credit supports and facilities because of the very high level of insecurity and volatility.

\section{Myth and believe of some heliolatry worshippers}

Some people still belief that the sun is the link between them and their life and as such, the sun is seen as their God of wisdom, justice, beneficiary and spiritual bond. This has resulted to the sun been revered and prayers and supplications rendered to it. Some heliolatry worshippers revere the sun and as a result see it as very wrong to tap and convert the solar energy into electricity utilization. Same ideology also goes for the wind and hydro.

\section{Lack of trained manpower in renewable energy}

One of the major challenges of RES development in developing countries is the lack of skilled/trained manpower. RES technology is evolving very fast, however skilled and trained manpower to match this pace of development is obviously lacking. The shortage of manpower and competency level has resulted to poor or no consideration of solar insolation, panel efficiency, specific consideration of geospatial angle of installation of the panels among others. Further research has showed that most RES programs are not too satisfactory in their course content, such that the RES industries do not find their relevance in tackling challenges ( be it practical or otherwise).This has resulted in making some of the RES industries to either hire skilled personnel or do in-house trainings through experts from developed nations. This in turn is very expensive for the company to also handle but they have no choice.

\section{Poor research facilities from the government and private bodies}

From International Renewable Energy Agency records (IREA), RES is expected to provide above $85 \%$ of global energy by 2050 . In order to meet this projection, most developed countries and industries alike have all established state of the art research institute and learning centers equipped with all required skilled manpower. Germany with the highest percentage of renewable energy utilization is $12.72 \%$, United Kingdom (UK) is the second with $11.92 \%$, followed by Spain $(10.17 \%)$, Italy $(9.08 \%)$ and Brazil (7.35\%). These countries have all reduced to a very large extent the dependency level on conventional fossil fuel source of power generation to achieve a better ecosystem. When compared to developing countries, the high dependency on fossil fuel has still not built the renewable energy industry. There is hardly any renewable energy industry that produces the required facilities and equipment either in part or in whole built in these developing countries not to imagine the research into some of the issues concerning RES technology.

\section{Importation of falsified and substandard res products}

Falsified and substandard equipment are imported into some developing countries mostly through the importers that though have the financial strength to import but lack the pre-requisite knowledge of renewable energy technology. There have been reported cases where some renewable energy products shipped into the developing countries are fake and fail to perform as designed. This has resulted to poor procurement of equipment and facility quality. More so some importers indulge in sharp practices with manufacturing companies and smuggled them into the countries. Among which range from deliberately importing facilities whose ratings are below its stated ratings yet make consumers pay for it to compromising/bribing constituted authorities that would have checked and corrected these criminal acts. When experts install these facilities, its performance output become less effective. This has actually destroyed the gradually built confidence about renewable energy utilization in most developing nations.

\section{Poor mapping data of res potentials in comparison with the environment}

Although most developing nations are blessed with abundance of renewable energy potentials such as wind, solar, hydro, biomass, etc., the level of utilization is extremely poor. Most developing countries want to harness these RES because of their peculiar characteristics of cleanness and cheapness of energy and also in terms of running cost though initial cost of installation is high. However, there is lack of available data to enable the government, policy makes, RES companies, public and other stake holders to understand fully these potentials and their exact locations and availability. Some nations such as Lesotho, New Guinea, Vietnam, Nigeria, Zambia Madagascar etc. have developed programs on mapping which is still in their initial phase, it is expected to address more serious issues relating to RES mapping currently and in the near future. The mapping is expected to also tackle matters such as validation of existing data and capacity building as well as creation and standardization of a comprehensive data base, carrying out geospatial output on both solar and wind and generation of global information of wind, solar and tidal data.

\section{Conclusion and Recommendation}

a. There should be deliberate attempt by the government through her educational agencies in developing nations to ensure that there is overall review of academic curriculum on 
RES applications from basic, nursery, primary, secondary, and tertiary institutions. This will involve incorporating basic/ modern concepts of RES in their course outline at all levels.

b. Qualified personnel should be involved and encouraged to transfer acquired knowledge to individuals, corporate organizations, companies, business owners, decision makers, owners of business and personnel involved in the business of res technology and its utilization and the public.

For possible submissions Click below: 